\title{
Synthesis, characterization and biological activities of transition metal chelates of 2-aminothiazole-derived Mannich bases
}

\author{
*P.Saravana Bhava ${ }^{1}$, P.Tharmaraj ${ }^{2}$, V.Muthuraj ${ }^{3}$, M.Umadevi $^{4}$ \\ ${ }^{1}$ Department of Chemistry, S.Vellaichamy Nadar Polytechinc College, Virudhunagar,India, \\ ${ }^{2}$ Department of Chemistry, Thiagarajar College, Madurai-9, India, \\ ${ }^{3}$ Research Department of Chemistry, VHNSN College, Virudhunagar, India, \\ ${ }^{4}$ PG \& Research Department of Chemistry, Nehru Memorial College, Puthanampatti, Tiruchirappalli, \\ Tamilnadu, India - 621007.
}

\begin{abstract}
Transition metal complexes of 2-aminothiazole-derived Mannich base ligand of the type $\mathrm{ML}_{2}$ [where $\mathrm{M}=\mathrm{Cu}(\mathrm{II}), \mathrm{Co}(\mathrm{II}), \mathrm{Ni}(\mathrm{II})$ and $\mathrm{Zn}(\mathrm{II})] \mathrm{L}=\mathrm{N}$-((1H-benzo[d][1,2,3]triazol-1-yl)methyl)thiazol-2-amine] have been synthesized. The structural features have been arrived from their elemental analysis, magnetic susceptibility, molar conductance, IR, UV-Vis, NMR, Mass and EPR spectral studies. Conductivity measurements reveal that all the complexes are non-electrolytic in nature. Spectroscopic and other analytical data of the complexes suggest octahedral geometry for $\mathrm{Cu}(\mathrm{II}), \mathrm{Co}(\mathrm{II}), \mathrm{Ni}(\mathrm{II})$ and $\mathrm{Zn}(\mathrm{II})$ complexes of $\mathrm{N}-((1 \mathrm{H}-$ benzo[d][1,2,3]triazol-1-yl)methyl)thiazol-2-amine metal(II) complexes. The redox behaviour of the copper(II) complexes have been studied by cyclic voltammetry. The free ligands and their metal complexes have been screened for their in-vitro biological activities against the bacteria Salmonella typhi, Pseudomonas aeruginosa, Escherichia coli and Bacillus subtilis and antifungal activities against the fungi Aspergillus niger, Aspergillus flavus and Rhizoctonia bataicola by well diffusion method. The zone of inhibition value indicates that the most of the metal complexes are found to possess increased activities than the free ligands. The binding properties of metal complexes with DNA were investigated by viscosity measurement. Detailed analysis reveals that the metal complexes intercalate into the DNA base stack as intercalators. The DNA cleavage ability of all the complexes were also examined on calf thymus (CT-DNA) plasmids using gel electrophoresis experiment in presence of $\mathrm{H}_{2} \mathrm{O}_{2}$ and the result implies that all the metal complexes cleave the CT-DNA in presence of $\mathrm{H}_{2} \mathrm{O}_{2}$.
\end{abstract}

Keywords: Mannich base, 2-aminothiazole, Benzotriazole, Biological activities, DNA cleavage. *Corresponding author

\section{INTRODUCTION}

Heterocyclic nitrogen plays an important role in coordination chemistry[1,2]. The triazole derivatives have discrete or super molecules in particular, benzotriazole displays remarkable efficiency as a corrosion inhibitor for copper and its alloys, and also very useful as fungicides and bactericides[3,4]. Benzotriazole was widely used in the construction of metal-organic frameworks due to the multifunctional linking role and an interesting case of linkage isomerization has been reported for benzotriazole complexe [5,6]. Moreover, the benzotriazole have two nitrogen atoms capable of coordination [7]. The 1-(H)-benzotriazole is found as an important heterocyclic compound. It's prime application is as corrosion inhibitors for copper or copper alloys $[8,9]$. Ciba Geigy has introduced benzotriazole derivative under the trade name Trinvin-P20. It is applied as an UV light absorber for stabilizing plastics and other organic materials against discoloration determination [10]. It is also employed as photographic emulsion stabilizer [11]. In the peptide synthesis it acts in the form of an active ester [12]. Biological systems of 2-aminothiazole and its derivatives are well known [20, 21]. The 2Aminothiazole moiety, proven its value in medicinal chemistry, has been successfully applied in dopamine agonists, such as B-HT920, PD118440 and pramipexole, the widely used anti-Parkinsonian agent [22]. In these cases, 2-aminothiazole group interact with nucleic acid to form a stable DNA-drug complex with the aid of hydrogen bonds formed between the amino group and the sugar-phosphate chain.

Mannich bases were found to possess potent activities such as anti-inflammatory, antibacterial and antifungal, antiviral, antifilarial, anticancer, antiparkinsons, and anti-HIV drugs [23-26]. They are also used in polymer industry as paints, surface active agents, and as anticonvulsant.

In the present research article we wish to report the synthesis, structure, anti-biogram and DNA binding and cleavage studies of some transition metal complexes of Mannich base of derivatives have been reported with a special impetus on ligand structural investigations. 
Synthesis, Characterization And Biological Activities of Transition Metal Chelates Of 2-

\section{Experimental}

All chemicals were obtained from Aldrich Chemical \& Co. and used without purification. The UV-Vis. spectra of the ligand and its metal complexes were recorded in DMSO using a JASCO V-530 spectrophotometer. IR spectra in $\mathrm{KBr}$ discs were recorded on a JASCO FT-IR 460 plus spectrophotometer at Thiagarajar College, Madurai. Cyclic voltammetry measurements were carried out at room temperature in DMSO (CH Instruments, USA, voltammograph) using a three-electrode cell containing a reference $\mathrm{Ag} / \mathrm{AgCl}$ electrode, Pt wire auxiliary electrode, and glassy carbon working electrode with tetrabutylammonium perchlorate (TBAP) as supporting electrolyte. Elemental analyses were performed at SAIF, CDRI, Lucknow. ${ }^{1} \mathrm{H}-\mathrm{NMR},{ }^{13} \mathrm{C}$ NMR spectra were recorded in $\mathrm{CDCl}_{3}$ using a Bruker DRX-300, $300 \mathrm{MHz}$ NMR spectrometer. EI mass spectra were recorded at IIT, Madras. EPR spectrum was recorded at SAIF, IIT, Bombay. Magnetic moments of the complexes were measured on a Magnetic Susceptibility Balance Mark 1 Sherwood UK at Thiagarajar College, Madurai. Effective magnetic moments were calculated using the formula $\mu$ eff $=2.828$ $(\mathrm{XMT})^{1 / 2}$ where $\mathrm{XM}$ is the molar susceptibility. Molar conductance of the complexes $\left(10^{-3} \mathrm{~mol} \mathrm{~L}^{-1}\right)$ was measured in DMF at room temperature using a Systronic conductivity bridge. Commercial solvents were distilled and then used for the preparation of ligands and their complexes. DNA was purchased from Bangalore Genei (India).

Microanalyses (C, H and N) were performed in Carlo Erba 1108 analyzer at Sophisticated Analytical Instrument Facility (SAIF), Central Drug Research Institute (CDRI), Lucknow, India.

\subsection{Synthesis of $\mathrm{N}$-((1H-benzo[d][1,2,3]triazol-1-yl)methyl)thiazol-2-amine [BTMTA]}

A mixture of Benzotriazole $1.1912 \mathrm{~g}(10 \mathrm{mmol})$, Formaldehyde $1.13 \mathrm{ml}(10 \mathrm{mmole})$ and 2 aminothiazole $0.9915 \mathrm{~g}$ (10 mmole) in $70 \mathrm{ml}$ ethanol was refluxed for 4 hours. Subsequently ethanol was distilled off and the residue obtained. It was trifurated with petroleum ether. A pale yellow colored solid obtained after refrigeration was recrystallised from dichloromethane. The yield obtained was $80 \%$, m.p. $90{ }^{\circ} \mathrm{C}$ (Figure 1.)

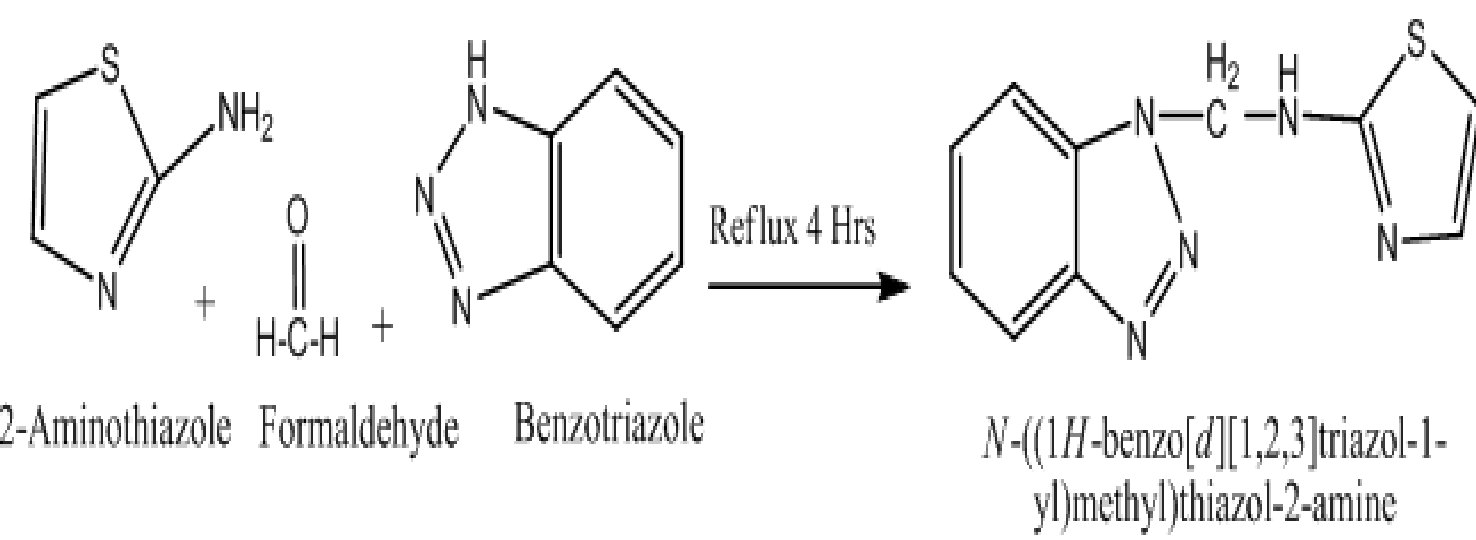

Figure 1. Synthesis of BTMTA

\subsection{Synthesis of metal(II) complexes}

All the complexes were prepared from hydrated metal salts. To a solution of $0.46 \mathrm{~g}(2 \mathrm{mmol}) \mathrm{N}-((1 \mathrm{H}-$ benzo[d][1,2,3]triazol-1-yl)methyl)thiazol-2-amine [BTMTA] in $20 \mathrm{~mL}$ ethanol, was added $2 \mathrm{mmol}$ of $\mathrm{MCl}_{2}$ . $\mathrm{xH}_{2} \mathrm{O}(\mathrm{M}=\mathrm{Cu}(\mathrm{II}), \mathrm{Co}(\mathrm{II})$ and $\mathrm{Ni}(\mathrm{II}), \mathrm{x}=2$ or 6$)$. The solution was refluxed at $70-80{ }^{\circ} \mathrm{C}$ under water bath with constant stirring for $3 \mathrm{~h}$ and the resulting solution was refrigerated for one day. The coloure complexes was precipitated by adding petroleum ether then filtered, washed with ethanol and dried under vacuum in high yield (75-80\%) m.p. $270-290{ }^{\circ} \mathrm{C}$

\section{RESULTS AND DISCUSSION}

The ligand BTMTA forms stable complexes with $\mathrm{Cu}(\mathrm{II}), \mathrm{Co}(\mathrm{II}), \mathrm{Ni}(\mathrm{II}))$ and $\mathrm{Zn}(\mathrm{II}) . \quad$ The analytical data of the ligand and the complexes together with their physical properties are given in Table 1. The molar conductance of the complexes implies that the complexes are non-electrolytes. The analytical data of the complexes are in good agreement with the general formula [ $\left.\mathrm{ML}_{2}\right]$ where $\left.\mathrm{M}=\mathrm{Cu}(\mathrm{II}), \mathrm{Co}(\mathrm{II}), \mathrm{Ni}(\mathrm{II})\right)$ and $\left.\mathrm{Zn}(\mathrm{II})\right]$. The magnetic moments show paramagnetic nature of $\mathrm{Cu}(\mathrm{II}), \mathrm{Co}(\mathrm{II})$, and $\mathrm{Ni}$ (II) complexes and indicate the sixcoordinate octahedral structure (Figure. 2) 
Table.1. Physical characterization, analytical and molar conductance data of the ligand (BTMTA) and its metal (II) complex.

\begin{tabular}{|c|c|c|c|c|c|c|c|c|c|c|}
\hline \multirow[b]{2}{*}{ Compound } & \multirow{2}{*}{$\begin{array}{c}\text { Formula } \\
\text { weight }\end{array}$} & \multirow[b]{2}{*}{ Color } & \multicolumn{5}{|c|}{ Fvaud (Culud) (96) } & \multirow[b]{2}{*}{$\begin{array}{l}\text { m,p. } \\
\left({ }^{\circ} \mathrm{C}\right)\end{array}$} & \multirow{2}{*}{$\begin{array}{l}\mu \text { eff } \\
\text { (B.M.) }\end{array}$} & \multirow{2}{*}{$\begin{array}{c}\sigma_{\mathrm{M}}\left(Z^{-1}\right. \\
\left.\mathrm{cm}^{2} \mathrm{~mol}^{-1}\right)\end{array}$} \\
\hline & & & M & $\mathrm{C}$ & $\mathrm{H}$ & $\mathrm{N}$ & S & & & \\
\hline $\mathrm{C}_{10} \mathrm{H}_{9} \mathrm{~N}_{5} \mathrm{~S}(\mathrm{BTMTA}) \mathrm{L} 4$ & 231 & Colorless & -. & $\begin{array}{l}51.90 \\
(51.93)\end{array}$ & $\begin{array}{c}3.88 \\
(3.92)\end{array}$ & $\begin{array}{c}30.24 \\
(30.28)\end{array}$ & $\begin{array}{r}13.80 \\
(13.86)\end{array}$ & 90 & $\ldots$ & $\ldots$ \\
\hline$[\mathrm{Cu}($ BTMTA $) 2](1)$ & 523 & Gray & $\begin{array}{c}12.10 \\
(12.13)\end{array}$ & $\begin{array}{l}45.80 \\
(45.84)\end{array}$ & $\begin{array}{c}3.04 \\
(3.08)\end{array}$ & $\begin{array}{l}26.70 \\
(26.73)\end{array}$ & $\begin{array}{c}12.20 \\
(12.24)\end{array}$ & $>290$ & 1.79 & 5.8 \\
\hline$[\mathrm{Co}($ BTMTA $) 2](2)$ & 519 & $\begin{array}{l}\text { Greenish } \\
\text { Brown }\end{array}$ & $\begin{array}{c}11.30 \\
(11.34)\end{array}$ & $\begin{array}{c}46.20 \\
(46.24)\end{array}$ & $\begin{array}{c}3.06 \\
(3.10)\end{array}$ & $\begin{array}{c}26.92 \\
(26.96)\end{array}$ & $\begin{array}{c}12.30 \\
(12.35)\end{array}$ & $>270$ & 4.94 & 6.7 \\
\hline Ni(BTMTA)] $](3)$ & 518 & Green & $\begin{array}{c}11.25 \\
(11.30)\end{array}$ & $\begin{array}{c}46.22 \\
(46.26) \\
\end{array}$ & $\begin{array}{c}3.06 \\
(3.11)\end{array}$ & $\begin{array}{l}26.94 \\
(26.98)\end{array}$ & $\begin{array}{c}12.31 \\
(12.35)\end{array}$ & $>290$ & 3.3 & 8.2 \\
\hline$[\mathrm{Zn}($ BTMTA $)],(4)$ & 524 & $\begin{array}{l}\text { Dark } \\
\text { yellow }\end{array}$ & $\begin{array}{c}12.40 \\
(12.44)\end{array}$ & $\begin{array}{c}45.62 \\
(45.67)\end{array}$ & $\begin{array}{l}3.03 \\
(3.07)\end{array}$ & $\begin{array}{l}26.58 \\
(26.63)\end{array}$ & $\begin{array}{c}12.14 \\
(12.19)\end{array}$ & $>280$ & $\ldots$ & 6.4 \\
\hline
\end{tabular}

\subsection{IR spectra}

The IR spectral data of the ligand and its complexes are given in Table 6.3. In order to study the binding mode of the ligand in the metal complexes, the IR spectrum of the free ligand was compared with those of the corresponding metal complex. The spectrum of the benzotriazole shows a weak band at $3198 \mathrm{~cm}^{-1}$ which belongs to $\mathrm{v}(\mathrm{NH})$, another weak band was observed at $3090 \mathrm{~cm}^{-1}$ which is attributed to $\mathrm{v}(\mathrm{C}-\mathrm{H})$ aromatic [27]. A strong band belongs to $\mathrm{V}(\mathrm{N}=\mathrm{N})$ was found at $1496 \mathrm{~cm}^{-1}$ [28]. The IR spectrum of the ligand displays bands at $1585 \mathrm{~cm}^{-1}$ which may be assigned to the $\mathrm{v}(\mathrm{C}=\mathrm{N})$ Thiazole ring and the band at $1496 \mathrm{~cm}^{-1}$ for $\mathrm{v}(\mathrm{N}=\mathrm{N})$ Benzotriazole ring. The infrared spectra of the prepared complexes exhibited the following bands: $\mathrm{v}(\mathrm{C}=\mathrm{N})$ in the region of 1593-1600 $\mathrm{cm}^{-1}$ which was shifted to lower frequencies by $10-15 \mathrm{~cm}^{-1}$ compared with 2aminothoazole spectrum, which indicates that the coordination with metal ions was through nitrogen atom. Thus, the band appeared at $1496 \mathrm{~cm}^{-1}$ belongs to $\mathrm{v}(\mathrm{N}=\mathrm{N})$ in benzotriazole moved to lower frequencies by 20-40 $\mathrm{cm}^{-1}$ which indicates the benzotriazole nitrogen coordinate with metal ions. The -NH group band appeared around $3419 \mathrm{~cm}^{-1}$ was still observed in metal(II) complex but it shifted to lower frequency and became less broad showing a peak centered around $3404 \mathrm{~cm}^{-1}$, indicating the coordination of hydrazo nitrogen to the metal ion via deprotonation. It has been reported that the presence of - $\mathrm{NH}$ band in the spectra of chelates and its shift to higher frequency indicates the involvement of the - $\mathrm{NH}$ lone pair of electrons in the coordination via deprotonation. The participation of three nitrogen atom coordination with the metal ion is further supported by the appearance of new bands at $636-624,550-520 \mathrm{~cm}^{-1}$ and $439-426 \mathrm{~cm}^{-1}$ which are attributed to $\vee(\mathrm{M}-\mathrm{N})[29$, 30]

Table 2. IR spectral data $\left(\mathrm{cm}^{-1}\right)$ of (BTMTA) and its metal(II) complexes

\begin{tabular}{|l|c|c|c|c|}
\hline \multicolumn{1}{|c|}{ Compound } & $\mathbf{v}(\mathbf{C}=\mathbf{N})$ & $\mathbf{v}(\mathbf{N}-\mathbf{H})$ & $\mathbf{v}(\mathbf{N}=\mathbf{N})$ & $\mathbf{v}(\mathbf{M}-\mathbf{N})$ \\
\hline $\mathrm{C}_{10} \mathrm{H}_{9} \mathrm{~N}_{5} \mathrm{~S}(\mathrm{BTMTA}) \mathrm{L} 4$ & 1585 & 3198 & 1496 & - \\
\hline$\left[\mathrm{Cu}(\text { BTMTA })_{2}\right](1)$ & 1600 & 3097 & 1448 & 520 \\
\hline$\left[\mathrm{Co}(\text { BTMTA })_{2}\right](2)$ & 1597 & 2970 & 1448 & 536 \\
\hline$\left[\mathrm{Ni}(\mathrm{BTMTA})_{2}\right](3)$ & 1550 & 3101 & 1448 & 637 \\
\hline$\left[\mathrm{Zn}\left(\mathrm{BTMTA}_{2}\right][(4)\right.$ & 1593 & 3099 & 1450 & 626 \\
\hline
\end{tabular}




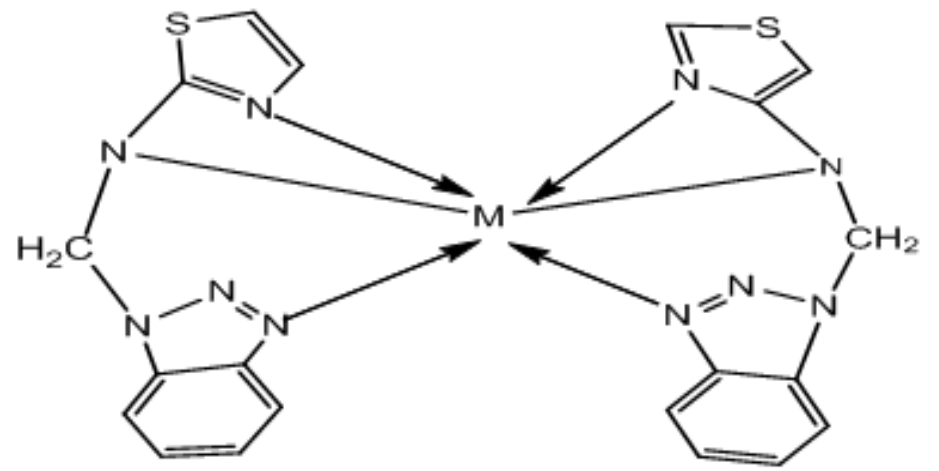

Figure. 2. Proposed structure of metal(II) complexes ( $\mathrm{M}=\mathrm{Cu}, \mathrm{Co}, \mathrm{Ni}$, and $\mathrm{Zn})$.

\subsection{NMR spectroscopy}

${ }^{1} \mathrm{H}$ NMR spectra of ligand (BTMTA) The $\mathrm{H}^{1}$ NMR spectra of ligand (BTMTA) and zinc(II) complex recorded in DMSO are assigned as follows. The spectrum of BTMTA exhibit the following signals phenyl multiplets at 6.9-7.5 $\delta,-\mathrm{N}_{-}-\mathrm{CH}_{2}$ at $3.2 \delta$, $-\mathrm{C}-\mathrm{NH}$ at $4 \delta$ and the peak at $7.4 \delta$ is attributed to thiazole $-\mathrm{CH}$. A thiazole proton of the free ligand at $\delta 7.4 \mathrm{ppm}$ also showed a downfield shift in the spectra of complexes providing an evidence for the coordination of the thiazole nitrogen to the metal atom. No appreciable changes were found in other signals of this complex. ${ }^{1} \mathrm{H}$ NMR Spectra of $\mathrm{Zn}(\mathrm{II})$ complex In the ${ }^{1} \mathrm{H}$ NMR spectrum of $\mathrm{Zn}$ (II) complex the aromatic protons have resonated in the region 7.2-842 $\delta$ as a multiplet. The signal due to $\mathrm{NH}$ at $10.6 \delta$ in ligand, disappears in case of complexes indicating the involvement of $\mathrm{NH}$ in the complexes formation via deprotonation.

${ }^{13} \mathrm{C}$-NMR spectra The ${ }^{13} \mathrm{C}$-NMR spectrum of the ligand shows the aromatic protons peaks at $[109.44$ $(\mathrm{CH}), 116.40(\mathrm{CH}), 123.84(2 \mathrm{CH}), 128.89(\mathrm{CH}), 132.80(\mathrm{C})] \mathrm{\delta}$. The peaks observed at $146.83 \delta$ for (thiadiazole $\mathrm{C}-2$ ), $147.07 \delta$ (triazole C-3), $154.028 \delta$ (thiadiazole C-5). The peaks observed at $55.89 \delta$ for $(\mathrm{NCH} 2)$.

\subsection{Mass spectra}

The EI-mass spectrum of ligand BTMTA and Co(II) complex were recorded. The molecular ion peak was observed at $231 \mathrm{~m} / \mathrm{z}$, whereas the Co(II) complex were observed at $519 \mathrm{~m} / \mathrm{z}$ respectively which corresponds to the molecular ion $\left[\mathrm{ML}_{2}\right]^{+}$. The mass fragmentation of the ligand [BTMTA] peaks exhibited peaks at, 218, $151,123,108$ and metal(II) complexes $\left(\mathrm{ML}_{2}\right)$ peaks exhibited peaks at $328,254,138$. The ligand fragmentation pattern followed the cleavage of $\mathrm{C}-\mathrm{N}, \mathrm{C}-\mathrm{C}$ and $\mathrm{C}=\mathrm{C}$ bonds. The $\mathrm{CoL}_{2}$ complex gives a molecular ion peak at $\mathrm{m} / \mathrm{z} 519\left(\mathrm{M}^{+}\right)$with a relative intensity of $10 \%$. The intensities of these peaks give the idea of the stability and abundance of the fragments. This type of stoichiometry $\left(\mathrm{ML}_{2}\right)$ is confirmed by the mass spectra of other complexes. This is in good agreement with the micro analytical data.

\subsection{Electronic spectral and magnetic moment data of the metal complexes}

The electronic spectral data of $\mathrm{Cu}(\mathrm{II}), \mathrm{Co}(\mathrm{II})$ and $\mathrm{Ni}(\mathrm{II})$, complexes of the ligand BTMTA were recorded in DCM and the spectral data are given in Table. 3 . The brown colored $\mathrm{Cu}$ (II) complex exhibit a broad asymmetric band in the region $12275-16262 \mathrm{~cm}^{-1}$ with maxima at $15194 \mathrm{~cm}^{-1}$ in an distorted octahedral geometry [31, 32]. The broadness of the band may be due to dynamic Jahn-Teller distortion and is assigned to ${ }^{2} \mathrm{~T}_{2 \mathrm{~g}} \rightarrow{ }^{2} \mathrm{E}_{\mathrm{g}}$ transitions. The copper(II) complex shows magnetic moment value at 1.79 B.M. for one unpaired electron supporting that these complexes possess structures within the range consistent to spin free distorted octahedral geometry. In the electronic spectra of $\mathrm{Co}(\mathrm{II})$ complex the two absorption bands observed at $18418 \mathrm{~cm}^{-}$ ${ }^{1}$ and $21734 \mathrm{~cm}^{-1}$ are due to ${ }^{4} \mathrm{~T}_{1 \mathrm{~g}}(\mathrm{~F}) \rightarrow{ }^{4} \mathrm{~A}_{2 \mathrm{~g}}(\mathrm{~F})\left(\mathrm{V}_{1}\right)$, and ${ }^{4} \mathrm{~T}_{1 \mathrm{~g}}(\mathrm{~F}) \rightarrow{ }^{4} \mathrm{~T}_{1 \mathrm{~g}}(\mathrm{P})\left(\mathrm{V}_{2}\right)$ transitions respectively. These transition suggest octahedral geometry for $\mathrm{Co}(\mathrm{II})$ complex, These assignments are in good agreement with the reported value [33]. Again, the six coordinate octahedral cobalt(II) complex was confirmed from the magnetic moment value 4.94 B.M, indicative of three unpaired electrons [34]. Ni(II)complexes exhibit three bands at $13005 \mathrm{~cm}^{-1}, 16558 \mathrm{~cm}-1$ and $20452 \mathrm{~cm}^{-1}$ are assigned to ${ }^{3} \mathrm{~A}_{2 \mathrm{~g}}(\mathrm{~F}) \rightarrow{ }^{3} \mathrm{~T}_{2 \mathrm{~g}}(\mathrm{~F})\left(\mathrm{V}_{1}\right),{ }^{3} \mathrm{~A}_{2 \mathrm{~g}}(\mathrm{~F}) \rightarrow{ }^{3} \mathrm{~T}_{1 \mathrm{~g}}(\mathrm{~F})\left(\mathrm{V}_{2}\right)$ and ${ }^{3} \mathrm{~A}_{2 \mathrm{~g}}(\mathrm{~F}) \rightarrow^{3} \mathrm{~T}_{1 \mathrm{~g}}(\mathrm{P})\left(\mathrm{V}_{3}\right)$ transitions respectively are in confirmatory with the octahedral geometry for the $\mathrm{Ni}(\mathrm{II})$ ion[35, 36]. The nickel(II) complex showed $\mu_{\text {eff }}$ value 3.3 B.M. characteristic of two unpaired electrons in nickel(II) ion for their ideal six coordinated configuration. The $\mathrm{Zn}(\mathrm{II})$ complex has been found to be diamagnetic in nature. By analogy with those described for the complexes containing N, S donor mannich bases and according to the empirical formulae of these complexes, an octahedral geometry is proposed. 
Synthesis, Characterization And Biological Activities of Transition Metal Chelates Of 2-

Table .3. Electronic spectral data $\left(\mathrm{cm}^{-1}\right)$ of the ligand BTMTA and its metal(II) complexes.

\begin{tabular}{|c|c|c|c|c|}
\hline Compound & Solvent & $\begin{array}{l}\text { Frequency } \\
\quad\left(\mathbf{c m}^{-1}\right)\end{array}$ & Transition & Geometry \\
\hline BTMTA & DMSO & 37458 & ILCT & ---- \\
\hline $\begin{array}{c}{[\mathrm{Cu}(} \\
\left.\text { BTMTA })_{2}\right]\end{array}$ & DMSO & 15194 & ${ }^{2} \mathrm{~T}_{2 \mathrm{~g}} \rightarrow{ }^{2} \mathrm{E}_{\mathrm{g}}$ & Octahedral \\
\hline $\begin{array}{c}{[\mathrm{Co}(} \\
\left.\text { BTMTA })_{2}\right]\end{array}$ & DMSO & $\begin{array}{l}18418 \\
21734\end{array}$ & $\begin{array}{l}{ }^{4} \mathrm{~T}_{1 \mathrm{~g}}(\mathrm{~F}) \rightarrow{ }^{4} \mathrm{~A}_{2 \mathrm{~g}}(\mathrm{~F}) \\
{ }^{4} \mathrm{~T}_{1 \mathrm{~g}}(\mathrm{~F}) \rightarrow{ }^{4} \mathrm{~T}_{2 \mathrm{~g}}(\mathrm{P})\end{array}$ & Octahedral \\
\hline$\left[\mathrm{Ni}(\mathrm{BTMTA})_{2}\right]$ & DMSO & $\begin{array}{l}13005 \\
16558 \\
20542\end{array}$ & $\begin{array}{l}{ }^{3} \mathrm{~A}_{2 \mathrm{~g}}(\mathrm{~F}) \rightarrow{ }^{3} \mathrm{~T}_{2 \mathrm{~g}}(\mathrm{~F}) \\
{ }^{3} \mathrm{~A}_{2 \mathrm{~g}}(\mathrm{~F}) \rightarrow{ }^{3} \mathrm{~T}_{1 \mathrm{~g}}(\mathrm{~F}) \\
{ }^{3} \mathrm{~A}_{2 \mathrm{~g}}(\mathrm{~F}) \rightarrow{ }^{3} \mathrm{~T}_{1 \mathrm{~g}}(\mathrm{P})\end{array}$ & Octahedral \\
\hline
\end{tabular}

\subsection{Electrochemical studies}

The cyclic voltammetric studies of the copper(II) complex was performed in acetonitrile solution at room temperature with tetrabutylammonium perchlorate (TBAP) as supporting electrolyte glassy carbon as working electrode Pt wire as auxiliary electrode and $\mathrm{Ag} / \mathrm{AgCl}$ as reference electrode scan rate $100 \mathrm{mV}(-0.2$ to $1.4 \mathrm{~V}$ ) shows a well-defined redox process. A cyclic voltammogram of $\mathrm{Cu}$ (II) displays two reduction peaks, first one at $E p_{c}=0.425 \mathrm{~V}$ with an associated oxidation peak at $E p_{\mathrm{a}}=0.3 \mathrm{~V}$ and second reduction peak at $E \mathrm{p}_{\mathrm{c}}=-0.95$ $\mathrm{V}$ with an associated oxidation peak at $\mathrm{Ep}_{\mathrm{a}}=-0.8 \mathrm{~V}$ respectively at a scan rate of $0.2 \mathrm{mV}$. The value of $\Delta \mathrm{Ep}$ is $0.125 \mathrm{~V}$ and $0.15 \mathrm{~V}$ for first and second redox couples respectively and increases with scan rate giving evidence for quasi-reversible nature associated with one electron reduction. The ratio of anodic to cathodic peak currents $\left(\mathrm{I}_{\mathrm{pc}} / \mathrm{I}_{\mathrm{pa}}=\sim 1\right)$ corresponding to a simple one-electron process was also reported by $\mathrm{R}$. Klement et al [37]. The peak current for the complex varies with scan rate and the $\Delta E_{p}=\left(E_{p a}-E_{p c}\right)$ values are greater than $200 \mathrm{mV}$ which, indicates that the reduction process are quasi-reversible in nature and a chemical changes occurs with the electron transfer [38]. The cyclic voltammogram of the copper (II) complex as shown in the fig. 3.

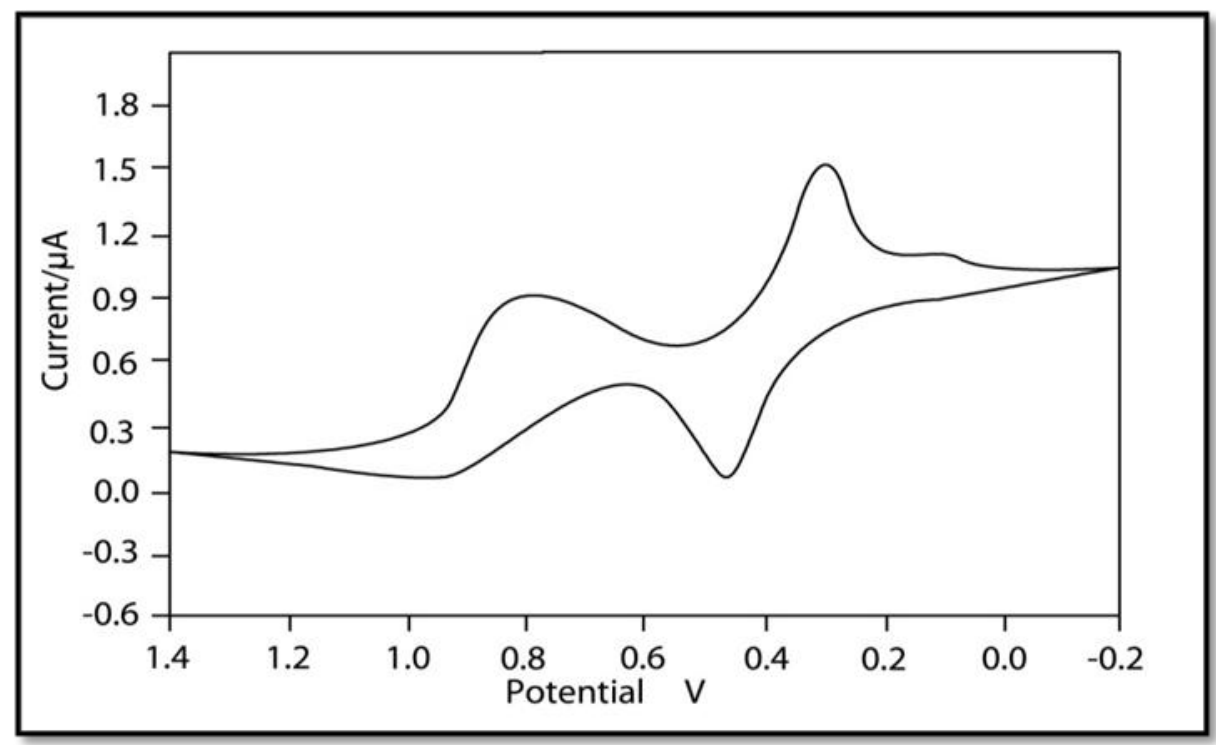

Figure. 3. Cyclic voltammogram of the copper(II) complex

\subsection{EPR spectra}

The EPR spectrum of copper(II) complexe provide information about hyperfine and super hyperfine structures. It is very important to understand the metal ion environment in the complexes, i.e., the geometry, nature of the donating atoms from the ligand and degree of covalency of the copper(II)-ligand bonds. The EPR spectra of the $\mathrm{Cu}$ (II) complexe were recorded in DMSO at liquid nitrogen temperature (LNT) and at room temperature (RT). g-Tensor values of copper(II) complexes can be used to derive the ground state. In an elongated octahedron, the $3_{\mathrm{d}}$ unpaired electrons for copper(II) ion lies in $\mathrm{d}_{\mathrm{x}-\mathrm{y}}{ }^{2}{ }^{2}$ orbital $\left({ }^{2} \mathrm{~B}_{1}\right.$ as ground state). In addition, exchange coupling interaction between two $\mathrm{Cu}(\mathrm{II})$ ions is explained by Hathaway expression $\mathrm{G}=\left(\mathrm{g}_{\|}\right.$ $-2) /\left(g_{\perp}-2\right)$. And the $G$ value large than 4 indicates that the exchange interaction is negligible. It has been 
reported (Table 6.4) that $\mathrm{g}_{\|}$value of copper (II) complex can be used as a measure of the covalent character of the metal-ligand bond. If the value is more than 2.3 , the metal-ligand bond is essentially ionic and the value less than 2.3 is indicative of covalent character [39]. The covalency parameter $\left(\alpha^{2}\right)$ indicates considerable covalent character for the metal-ligand bond [40]. Also the trend $g_{\|}>g_{\perp}>g_{e}$ (2.0027) observed for these complexes indicates that the unpaired electron is most likely in the $d_{x 2-y_{2}}$ orbital of the $\mathrm{Cu}$ (II) ion in complexes [41]. The EPR spectral assignments of the $\mathrm{Cu}$ (II) complexes are presented in Table 6.4 and spectra of the $\mathrm{Cu}$ (II) complexe are given in Fig. 6.7. a) and b) The EPR parameters $g_{\|}, g_{\perp}, g_{a v}, A_{\|}$and $A \perp$ and the energies of the $d-d$ transitions were used to evaluate the bonding parameters (Table 6.4) $\alpha^{2}, \beta^{2}$ and $\gamma^{2}$ which may be regarded as measurement of covalency of the in-plane $\sigma$-bonding, in-plane $\pi$-bonding and out of plane rrbonding respectively. The value of $\alpha^{2}$ and $\beta^{2}$ were estimated from the following expression [42].

$$
\begin{aligned}
& \alpha^{2}=-(\mathrm{A} \| / 0.036)+(\mathrm{g} \|-2.0027)+(3 / 7)(\mathrm{g} \perp-2.0027)+0.04 \\
& \beta^{2}=(\mathrm{g} \|-2.0027) \mathrm{E} /-8 \lambda \alpha^{2}
\end{aligned}
$$

According to Hathaway $\mathrm{K}_{\|} \approx \mathrm{K}_{\perp} \approx 0.77$ for pure in-plane $\sigma$-bonding and $\mathrm{K}_{\|}<\mathrm{K} \perp$ for in-plane $\pi$-bonding, while for out of plane rrbonding $\mathrm{K}_{\|}>\mathrm{K} \perp$. In the $\mathrm{Cu}$ (II) complexes, it is observed that $\mathrm{K}_{\|}<\mathrm{K} \perp$ indicates the presence of significant in-plane r rbonding than from out of plane $\pi$-bonding in metal-ligand $\pi$-bonding. $K$ is dimensionless quantity, which is a measure of the contribution of s electrons to the hyperfine interaction and is generally found to have a value of 0.30 . The $\mathrm{K}$ values obtained for all the complexes are in agreement with those estimated by Assour [43] and Abragam and Pryce [44].

Hence, the EPR study of the copper(II) complex has provided supportive evidence to the conclusion obtained on the basis of electronic spectra and magnetic moment values. Thus, the results confirmed that, the $\mathrm{Cu}$ (II) complex possess distorted octahedral geometry.

Table .4. EPR spectral parameters of $\mathrm{Cu}(\mathrm{II})$ complex

\begin{tabular}{|c|c|l|l|l|l|}
\hline \multirow{2}{*}[\mathrm{Cu}(\mathrm{BTMTA})_{2}]{} & $\mathrm{g}_{\|}$ & $\mathrm{g}_{\perp}$ & $\mathrm{g}_{\mathrm{av}}$ & $\mathrm{g}_{\text {iso }}$ & $\mathrm{G}$ \\
\cline { 2 - 6 } & 2.257 & 2.059 & 2.12 & 2.20 & 4.4 \\
\hline
\end{tabular}

\subsection{Molar conductance}

Values of molar conductance of the complexes are given in Table 1. The low values in DMF indicate that the complexes are non electrolytes.

\subsection{Biological activity}

The ligand BTMTA and its metal(II) complexes were evaluated for antimicrobial activity by the well diffusion method [45] against the bacteria Salmonella typhi, Pseudomonas aeruginosa, Escherichia coli and Bacillus subtilis using agar nutrient as the medium and antifungal activities against the fungi Aspergillus niger, Aspergillus flavus and Rhizoctonia bataicola cultured on potato dextrose agar as medium. The stock solution $\left(10^{-3} \mathrm{M}\right)$ was prepared by dissolving the compounds in DMSO. The antimicrobial activities were performed in triplicate and the average was taken as the final reading.

The well was made on the agar medium inoculated with microorganisms and filled with the test solution. The plate was incubated for $24 \mathrm{~h}$ for bacteria and $72 \mathrm{~h}$ for fungi at $35^{\circ} \mathrm{C}$. During this period, the test solution was diffused and the growth of the inoculated microorganisms were affected. The inhibition zone was developed and it was measured. Zone of inhibition of the investigated compounds against the bacteria and fungi are summarized in Table.5.

Streptomycin and nystatin were used as standard reference compounds for antibacterial and antifungal activities. The observed values show that most of the complexes have higher activity than the free ligand. Such an increased activity of the complexes can be explained on the basis of particle size and chelation theory [46, 47]. On chelation, the polarity of the metal ion will be reduced to a greater extent due to the overlap of the ligand orbital and partial sharing of positive charge of the ligand orbital and donor groups. This, in turn, will increase the lipophilic character of the metal chelate and favors its permeation through the lipid layers of the bacterial membranes [48]. The mode of the action of compounds may involve the formation of hydrogen bond through azomethine group with the active center of cell constituents resulting in interference with normal cell process. 
Synthesis, Characterization And Biological Activities of Transition Metal Chelates Of 2-

\begin{tabular}{|c|c|c|c|c|c|c|c|}
\hline \multirow[b]{2}{*}{ Compounds } & \multicolumn{7}{|c|}{ Zone of inhibition $(\mathrm{mm})^{*}$} \\
\hline & S. typhi & $\begin{array}{c}P . \\
\text { aeruginosa }\end{array}$ & E. coli & B. subtilis & A. niger & A. flavus & R. bataicola \\
\hline $\begin{array}{l}\mathrm{C}_{10} \mathrm{H}_{9} \mathrm{~N}_{5} \mathrm{~S}( \\
\text { BTMTA }\end{array}$ & 4.1 & 6.0 & 5.4 & 3.6 & 4.8 & 5.2 & 5.3 \\
\hline$\left[\mathrm{Cu}(\mathrm{BTMTA})_{2}\right]$ & 6.2 & 11.0 & 7.5 & 6.1 & 6.0 & 6.8 & 7.8 \\
\hline$\left[\mathrm{Co}(\mathrm{BTMTA})_{2}\right]$ & 6.0 & 11.5 & 5.6 & 4.6 & 6.2 & 7.2 & - \\
\hline$\left[\mathrm{Ni}(\mathrm{BTMTA})_{2}\right]$ & 4.3 & 10.4 & 6.1 & 4.2 & 4.6 & 7.0 & - \\
\hline$\left[\mathrm{Zn}(\mathrm{BTMTA})_{2}\right]$ & 4.6 & 10.5 & 8.2 & 5.2 & 5.3 & 5.8 & 5.6 \\
\hline $\begin{array}{l}\text { Streptomycin } \\
\text { and mystatiz }\end{array}$ & 11.0 & 16.0 & 16.0 & 12.0 & 10.0 & 8.6 & 14.0 \\
\hline
\end{tabular}

${ }^{*}$ The test was done using $10^{-3} \mathrm{M}$ concentration of metal(II) complexes by well diffusion technique. The values are mean of three replications.

\subsection{DNA-binding Studies}

DNA binding experiments were carried out in $0.5 \mathrm{~mL}$ Tris- $\mathrm{HCl} / \mathrm{NaCl}$ buffer $[50 \mathrm{mM}$ Tris- $\mathrm{HCl}$ and 5 $\mathrm{mM} \mathrm{NaCl}(\mathrm{pH}$ 7.2)] using DMF solution $(15 \mu \mathrm{L})$ of the complexes. Absorption titration measurements were done by varying the concentration of CT DNA but keeping the metal complex concentration as constant. The different modes of interaction of a metal complex with DNA can be studied not only by this technique but also cyclic voltammetry (CV) and differential pulse voltammetry (DPV). These were employed to probe the binding of metal complexes to DNA in solution. DPV data were used to obtain quantitative information about the interaction of these metal complexes with CT DNA. Due to its sensitivity to the change of length of DNA, viscosity measurement may be the most effective means to study the binding mode of complex to DNA, especially in the absence of crystallographic structure data. Flow time was measured with a digital stopwatch, and each sample was measured three times, and an average flow time was calculated. Data were presented as ( $\eta$ / $\left.\eta^{0}\right)^{1 / 3}$ versus binding ratio [49], where $\eta$ is the viscosity of CT DNA in the presence of complex, and $\eta^{0}$ is the viscosity of CT DNA alone.

\subsubsection{Viscosity Measurements}

Viscosity measurements at room temperature were performed using a semi-micro dilution capillary viscometer. Each experiment was performed three times and an average flow time was calculated. The data are presented as $\left(\eta / \eta_{0}\right)^{1 / 3} v s$. the binding ratio, where $\eta$ is the viscosity of a DNA solution in the presence of a complex and $\eta_{0}$ is the viscosity of DNA in solution alone.

The application of an optical photophysical technique to investigate the interactions of DNA with metal complexes generally provides clues that are needed but not sufficient by themselves to support an intercalative binding model. Therefore, viscosity measurements were introduced to provide further support for this type of interaction between the complexes and DNA. In the absence of crystallographic structural data, hydrodynamic methods which are sensitive to the length of the DNA are known to be among the definitive and critical indicators of binding strength. Intercalation is an effect of increasing the viscosity of DNA [50-52]. The significant increase in the viscosity of DNA that occurred upon the addition of a complex was due to intercalation, which caused the DNA bases to separate in order to the increase the effective size of the DNA, which could be the reason for the increase in the viscosity. A plot of $\left(\eta / \eta_{0}\right)^{1 / 3}$ vs $[$ complex]/[DNA] (R) gives a measure of the change in viscosity.

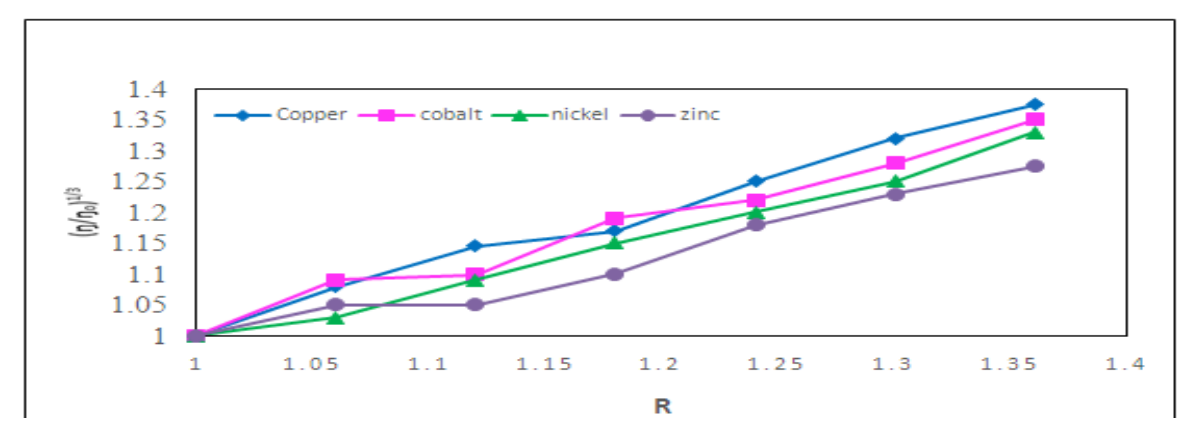

Fig. 4. Effect of increasing amounts of $\left[\mathrm{Cu}(\mathrm{L} 3)_{2} .2 \mathrm{H}_{2} \mathrm{O}\right](\bullet),\left[\mathrm{Co}(\mathrm{L} 3)_{2} .2 \mathrm{H}_{2} \mathrm{O}\right](\boldsymbol{\bullet}), \quad\left[\mathrm{Ni}(\mathrm{L} 3)_{2} .2 \mathrm{H}_{2} \mathrm{O}\right](\boldsymbol{\nabla})$ $\left[\mathrm{Zn}(\mathrm{L} 3)_{2} .2 \mathrm{H}_{2} \mathrm{O}\right](\bullet)$, on the viscosity of DNA. $\mathrm{R}=[$ complex]/[DNA] 
From the Fig. 4, a gradual increase in the relative viscosity was observed upon the addition of the metal complexes to the DNA solution, suggesting that the complexes mainly bind via an intercalation mode. Not only does this result give sign of an intercalative binding mode of the complex, but it is also in agreement with the pronounced hypochromism and bathochromism of the complexes in the presence of DNA.

\subsection{DNA cleavage activity of metal(II) complexes}

The oxidative cleavage activity of the complexes of BTMTA was studied by gel electrophoresis using calf thymus DNA $(15 \mu \mathrm{l})$ in Tris- $\mathrm{HCl}$ buffer $(\mathrm{pH}=7.0)$. Selected CT-DNA cleavage activity of the gel diagram is shown in Fig.6.10. The gel electrophoretic to conduct electrophoresis with such systems including DNA alone, DNA- $\mathrm{H}_{2} \mathrm{O}_{2}-\mathrm{M}$ (II) $(\mathrm{M}=\mathrm{Cu}$ (II), $\mathrm{Co}(\mathrm{II}), \mathrm{Ni}(\mathrm{II}), \mathrm{Zn}$ (II) and $\mathrm{Mn}$ (II)) complexes, which were prepared under the same condition and kept at $2 \mathrm{~h}$ in order to eliminate the influence of the reaction speed. The cleavage activity of the complexes were carried out for $2 \mathrm{~h}$ exposure. The cleavage efficiency of the complexes compared with that of the control is due to their efficient DNA-binding ability. The metal(II) complexes are able to convert super coiled DNA into open circular DNA [53].

The general oxidative mechanisms proposed to account for DNA cleavage by hydroxyl radicals via. abstraction of a hydrogen atom from sugar units and predict the release of specific residues arising from transformed sugars, depending on the position from which the hydrogen atom is removed [54]. From Fig.5. (lanes 2-6), it is evident that the complexes cleave DNA more efficiently in the presence of an oxidant $\left(\mathrm{H}_{2} \mathrm{O}_{2}\right)$. This may be attributed to the formation of hydroxyl free radicals. The $\mathrm{OH}$ free radicals participate in the oxidation of the deoxyribose moiety, followed by hydrolytic cleavage of a sugar phosphate back bone. All the complexes showed pronounced nuclease activity in the presence of oxidant $\mathrm{H}_{2} \mathrm{O}_{2}$ which may be due to the increased production of hydroxyl radicals $[55,56]$. Control experiments using DNA alone (lane 1) did not show any significant cleavage of CT DNA even on longer exposure time. From the observed results, it is concluded that all the complexes effectively cleave the DNA as compared to control DNA.

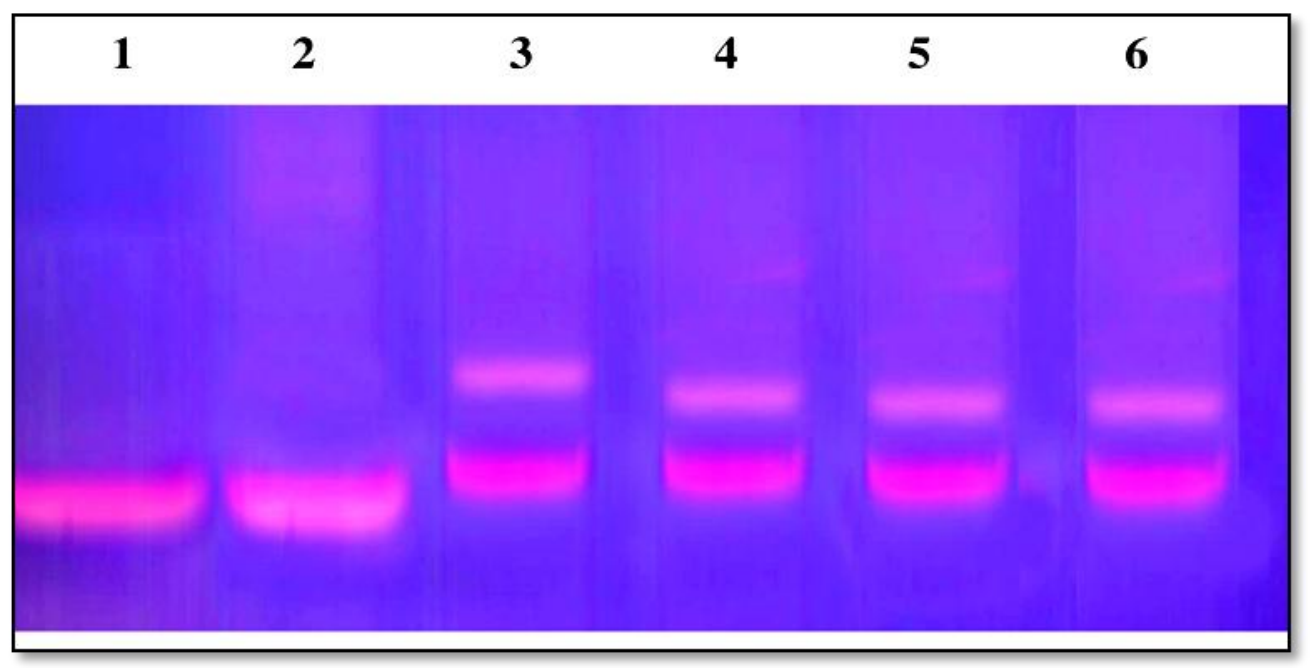

Figure.5. Changes in the gel electrophoretic pattern of CT- DNA induced by $\mathrm{H}_{2} \mathrm{O}_{2}$ and $\mathrm{Cu}(\mathrm{II}), \mathrm{Co}(\mathrm{II}), \mathrm{Ni}(\mathrm{II})$ and $\mathrm{Zn}$ (II) complex,

Lane 1: DNA alone

Lane 3: DNA + $\mathrm{Cu}(\mathrm{II})$ complex $+\mathrm{H}_{2} \mathrm{O}_{2}$

Lane 5: DNA + Ni(II)complex $+\mathrm{H}_{2} \mathrm{O}_{2}$
Lane 2: DNA+ BTMTA + $\mathrm{H}_{2} \mathrm{O}_{2}$

Lane 4: DNA + $\mathrm{Co}(\mathrm{II})$ complex $+\mathrm{H}_{2} \mathrm{O}_{2}$

Lane 6: DNA $+\mathrm{Zn}(\mathrm{II})$ complex $+\mathrm{H}_{2} \mathrm{O}_{2}$

In the present study the CT-DNA gel electrophoresis experiment was carried out at $35^{\circ} \mathrm{C}$ using our synthesized complexes in presence of $\mathrm{H}_{2} \mathrm{O}_{2}$ as an oxidant. It was found that, few complexes exhibit nuclease activity in presence of $\mathrm{H}_{2} \mathrm{O}_{2}$. Control experiment using DNA and DNA $+\mathrm{H}_{2} \mathrm{O}_{2}$ does not show any significant cleavage of CT-DNA even on longer exposure time. Hence, we conclude that the $\mathrm{Cu}$ (II), $\mathrm{Co}$ (II), $\mathrm{Ni}$ (II) and $\mathrm{Zn}$ (II) complexes cleaves DNA as compared with control DNA in the presence of $\mathrm{H}_{2} \mathrm{O}_{2}$. Further, the presence of a smear in the gel diagram indicates the presence of radical cleavage [57]. 
Synthesis, Characterization And Biological Activities of Transition Metal Chelates Of 2-

\section{CONCLUSION}

A novel mannich base has been designed and synthesized using the bioactive ligand obtained from benzotriazole, formaldehyde and 2-aminothiazole. Its $\mathrm{Cu}(\mathrm{II}), \mathrm{Co}(\mathrm{II}), \mathrm{Ni}(\mathrm{II}), \mathrm{Zn}$ (II) complexes have also been synthesized in ethanol medium. The structural features have been arrived from their elemental analyses, magnetic susceptibility, molar conductance, IR, UV-Vis., ${ }^{1} \mathrm{H}$ NMR, ${ }^{13} \mathrm{C}$ NMR, Mass, and EPR spectral studies. The data show that the complexes have composition of $\mathrm{ML}_{2}$ type. The electronic absorption spectral data of the complexes suggest an octahedral geometry around the central metal ion. Electrochemical studies of the $\mathrm{Cu}$ (II) compound implies that the redox reaction in one electron transfer with quasi-reversible character. The binding of these complexes to CT-DNA was investigated in detail via viscosity measurements and the result reveal that all the complexes can interact with DNA through an intercalative binding mode. The interaction of metal(II) complexes with CT-DNA has been investigated by gel electrophoresis. From the results, it is found that the metal complexes cleaved DNA efficiently in the presence of $\mathrm{H}_{2} \mathrm{O}_{2}$ as compared to the control DNA. The therapeutic promise of the investigated metal(II)complexes were found to exhibit higher antimicrobial activity than the ligand.

\section{ACKNOWLEDGMENTS}

The authors thank the Management of Thiagarajar College, Madurai, and the Management of S.Vellaichamy Nadar Polytechnic College, Virudhunagar. P.Saravana bhava one of the author thanks to Directorate of Technical education, Chennai, for permitting him to do his Ph.D. The authors thanks to SAIF, IIT, Bombay and CDRI, (SAIF) Lucknow for providing analytical facilities.

\section{REFERENCE}

[1]. J. G. Reedijk, R. Wilkinson, J. Gillard, Cleverty, Journal of Chemical Crystallography 29, 1999, 299308.

[2]. C. R. Reginaldo, N. R. Francisca, E. T. Henrique, J Braz Chem Soc, 12, 2001, 234

[3]. J. Wang, Y. Ming, Y. Yang, F. Miao, Chinese Science Bulletin, 47, 2002, 890.

[4]. M. H. O'Leory, Contemporary Organic Chemistry; University of Wis-consin, (McGraw-Hill book company, New York, 1976)

[5]. Y. S. Cheng, J. L. Zhao, K. C. Jian, Y. Q. Yan, Y .Yuan, Inorg Chem Comm, 10(8), 2007, 888-890.

[6]. E. T. Henrique, C. R. Reginaldo, Croatica Chemica Acta, 74, 2001, 499-528.

[7]. R .Chris, J. S. Peter, Dalton Trans. 992. 2003, 8.

[8]. J. W. Long, L. V. Vecek, (Sherwin-Williams Co U S, 1982), 4663914.

[9]. F. Hageolorn, W. Evertz, U. S. Bayer, (Ullman's Encyclopedia of Industrial Chem Willey, 1984) 4424360, 3.

[10]. N. J. Rahway, The Merk Index 11th Ed Merk \& Co., 1981.

[11]. Ullman's Encyclopedia of Industrial Chemistry, (Willey Veh, 1984), 26, 614.

[12]. D. Hadson, R. C River, G. E. Marshell, Peptides Chem. \& Biology, 1990.

[13]. A.A. Soliman, G.G. Mohamed., Thermochim Acta, 421, 2004, 151-159.

[14]. S.M. Abdallah., M.A. Zyed, G.G. Mohammed., Arabian J. Chem, 3, 2010, 103-113.

[15]. S. Chandra, R. Kumar, Trans. Met. Chem, 29, 2004, 269-275.

[16]. S.G. Shirodkar., P.S. Mane, T.K. Chondhekar., Indian J. Chem. 40A, 2001, 1114-1117.

[17]. M.A. Neelakantan, S.S. Marriappan, J. Dharmaraja., T. Jeyakumar, K .Muthukumaran., Spectrochim. Acta,71A, 2008, 628-635

[18]. S. Ershad, L. A. Sagathforoush, G. Karim-nezhad, S. Kangari., Int. J. Electrochem. Sci., 4, 2009, 846854.

[19]. N. Raman., S. J. Raja, J. Joseph, J. D. Raja., J. Chil. Chem. Soc., 52, 2007, 1138-1144

[20]. M. Van Bensichem, N. Farrell; Inorg. Chem. 31, 1992, 639.

[21]. N. Farrell, Y. Qu, L. Feng, B. Van Houten ,Biochemistry; 29, 1990, 9522

[22]. Zhang, W. Xiong, J. E. Hilbert, E. K. DeVita, J. M. Bidlack, J. L. Neumeyer,. J. Med. Chem. 47, 2004, 1886-1888

[23]. Kalluraya, M. Ramesh, M. Chimbalkar, J.C. Hedge. Indian J Heterocycl Chem; 15(1), 2005, 15-8.

[24]. B.S. Holla, M.K. Shivananda, B. Veerendra, B. Poojary. Indian J Heterocycl Chem, 15(1), $2005,75-$ 6 
[25]. T.B. Shah, A. Gupte, M.R. Patel, V. S. Chaudhari, H. Patel, V.C. Patel. Indian J Chem; 48B (7), 2009, $88-96$

[26]. S.Vijayraghavan, R.R. Somani, P.Y. Shirodhar, Indian J Heterocycl Chem, 18(2), 2008, 137-40.

[27]. William and Fleming, Spectroscopic Methods in Organic Chemistry, (2nd Edn.,

[28]. McGraw-Hill: London, New York, 1973).

[29]. Shayma, E-Journal of Chemistry. 7(4), 2010, 1598-1604.

[30]. Vidyavati reddy, Nirdosh patil, Tukaram reddy and S.D. Angadi, E-Journal of Chemistry, 5, 2008, 529-538

[31]. C. Fabretii, G. C. Grancini, G. Peyronet, Spectrochim. Acta, 26A, 1985, 698.

[32]. F. Rafat, K. S. Siddiqi, M.Y. Siddiqi, Polish J Chem. 79(4), 2005, 663

[33]. A.P. Mishra, H. Purwar, K. Rajendra, Jain, S.K. Gupta E-Journal of Chemistry, 9(4), 2012, 1655-1666

[34]. N. Raman, S. Ravichandran, C Thangaraja, J. Chem. Sci., 4, 2004, 215-219.

[35]. M.M. Aboaly and M.M.H. Khalil, Spectrosc. Lett., 34, 2001, 498

[36]. S. Chandra, K. Gupta, Trans. Met. Chem. 27, 2002, 329

[37]. C.M. Sharaby. Spectrochim. Acta, 62, 2005, 326

[38]. R. Klement, F. Stock, H. Elias, H. Paulus, P. Pelikan, M. Valko, M. Mazur, Polyhedron 18, 1999, 3617.

[39]. K.G. Dutton, G.D. Fallon, and K.S. Murray, Inorg. Chem., 27, 1988, 34

[40]. P. Kamalakannan, D. Venkappayya, Russ. J. Coord. Chem. 28, 2002, 423.

[41]. S.N. Shetti, A.S.R. Murty, G.L. Tembe, Indian J. Chem. 32A, 1993, 318.

[42]. K.B. Gudasi, S.A. Patil, R.S. Vadavi, R.V. Shenoy, Trans. Met. Chem. 31, 2006, 586.

[43]. D. Kivelson, R. Neiman, J. Chem. Soc., Dalton Trans. 35, 1961, 149.

[44]. M. Assour, J. Chem. Phys. 43, 1965, 2477.

[45]. Abragam, M.H.L. Pryce, Proc. R. Soc. Lond. A.206, 951, 164.

[46]. O.N. Irobi, M. Moo-Young and W.A. Anderson, Int. J. Pharm., 34, 1996, 87

[47]. P.B. Chakrawarthi, J. Indian Chem. Soc., 78, 2001, 273

[48]. R.K. Ray and G.R. Kauffman, Inorg. Chem. Acta, 173, 2001, 207

[49]. R.N. Patel, N. Singh and D.K. Patel, Indian J. Chem., 46A, 2007, 422

[50]. G. Cohen, H. Eisenberg, Biopolymers 8, 1969, 45. S. Satyanarayana, J.C. Daborusak, J.B. Charies, Biochemistry, 32, 1993, 2573-2584.

[51]. S. Satyanarayana, J.C. Dabroniak, J.B. Chaires, Biochemistry 31, 1992, 9319.

[52]. J.G. Liu, B.H. Ye, H. Li, Q.X. Zhen, L.N. Ji, Y.H. Fu, J. Inorg.Biochem. 76, 1999, 265.

[53]. G. Prativel, M. Pitie, J. Bernadou, B. Meunier, Angew Chem. Int. Ed. Engl., 30, 1991, 702

[54]. A.M. Thomas, A.D. Naik, M. Nethaji and A.R. Chakravarty, Indian J. Chem., 43A, 2004, 691

[55]. S. Sobha, R. Mahalakshmi, N. Raman, Spectrochimica Acta, 92, 2012, 175- 183.

[56]. N. RAMAN, S. SOBHA, J. Serb. Chem. Soc. 75 (6), 2010, 773-788

[57]. V. Uma, M. Kanthimathi, J. Subramanian and B.U. Nair, Biochim. Biophys. Acta, 814, 2006, 1760 